\title{
Serotonin Antagonist
}

National Cancer Institute

\section{Source}

National Cancer Institute. Serotonin Antagonist. NCI Thesaurus. Code C66885.

Any agent that binds to and blocks serotonin receptors. 